\title{
Effects of competition with weeds on growth, development and yield of groundnuts
}

\section{A.P. EVERAARTS ${ }^{1}$}

Centre for Agricultural Research in Suriname (CELOS), Anton de Kom University of Suriname, Paramaribo, Suriname, Departments of Tropical Crop Science and Vegetation Science, Plant Ecology and Weed Science, Wageningen Agricultural University, Bornsesteeg 69, NL 6708 PD Wageningen, Netherlands

Received: 28 August 1991; accepted: 17 December 1991

\begin{abstract}
Competition between weeds and groundnuts (Arachis hypogaea L.) was studied in two field experiments. The crop was kept weed-free or without weed control for increasing periods of time after planting. Observations made at the end of each period with or without weed control provided an analysis of the growth of a crop with weed control and of a crop without weed control. Uncontrolled weed growth was concentrated between the rows. Competition with weeds reduced ground-cover and leaf area index of the crop. Dry matter accumulation was affected, resulting in lower yields. Plant density and number of branches per plant were not influenced. Weed competition increased stem length and reduced the number of leaves and pods per plant. Timing of flowering was not influenced. Competition for nutrients was absent, but there was competition for light and water. About 15 weed-free days after planting were sufficient to prevent yield losses. Yield losses were due to a reduction in number of pods per plant. Competition should especially be prevented in the period when the number of pods per plant is established, i.e. around 35-60 days after planting.
\end{abstract}

Keywords: groundnuts, Arachis hypogaea, weed competition, growth analysis, nutrient uptake, pod formation, distribution of weed growth, humid tropics, Suriname

\section{Introduction}

In many tropical countries, weed competition may cause serious yield losses in groundnuts (Arachis hypogaea L.) (Goldson, 1967; Ishag, 1971; Carson, 1976; Rethinam et al., 1976; Drennan \& Jennings, 1977; Lagoke et al., 1981; Yadav et al., 1984; Hamada et al., 1988).

Competition between crop and weeds may vary, among other factors, with local conditions (Smartt, 1964; Schiller et al., 1976), cultivars (Brown, 1965), fertilizer application (Ashrif, 1967), season (Hamdoun, 1977) and type of weed flora (Hamada, 1988).

\footnotetext{
${ }^{1}$ Present address: Research Station for Arable Farming and Field Production of Vegetables (PAGV),
} P.O. Box 430, NL 8200 AK Lelystad, Netherlands. 


\section{A.P. EVERAARTS}

The published results suggest that, in general, weeding during the first four to about eight weeks after planting is essential to prevent yield losses.

Research results and practical experience regarding weed control in groundnuts in Suriname have been discussed by Dumas \& Ausan (1978). In the only study on competition (Oomkes, unpublished), a six week period after planting without weed control caused no yield reduction, but an eight week period reduced the yield. Without any weed control yield reduction was 54 percent. This study was done in the coastal plain of Suriname.

In recent years interest developed in the cultivation of groundnuts in the inland Zanderij area of Suriname (Janssen \& Wienk, 1990). Little was known about the effect of weeds on crop growth and production under the local conditions. Therefore research on crop-weed competition was started.

This paper reports the results of two experiments in which the effects of weeds on growth, development and yield of groundnuts in the inland Zanderij area were studied.

\section{Materials and methods}

\section{General}

The experiments were carried out at the experimental farm Coebiti $\left(5^{\circ} 20^{\prime} \mathrm{N}\right.$, $55^{\circ} 30^{\prime} \mathrm{W}$ ), during the late long rainy season of 1982 (Experiment 1) and the short rainy season of 1982-83 (Experiment 2). Data on rainfall during the experiments are presented in Figure 1.

To evaluate competition for water between crop and weeds, potential evapotranspiration of the crop during the experiments was calculated as free water evaporation $\times$ crop coefficient (Figure 1). Free water evaporation was calculated according to the Penman equation, as amended by Doorenbos and Pruitt (1977). Based on crop development and the indications given by Doorenbos \& Pruitt (1977), the crop coefficient was taken as 0.45 during the first 10 days after planting (DAP), subsequently increasing linearly to 0.95 at mid-season (45 DAP) and then decreasing linearly from 80 DAP onwards to 0.55 at harvest.

The soils of the experimental fields are a predominantly sandy (Experiment 1) and a sandy loam soil (Experiment 2) and are acid and of low fertility. They are classified as yellow kaolinitic Oxisols intergrading towards Ultisols. Soil chemical properties are given in Table 1 .

\section{Cultivation practices}

The experimental fields were limed at the rate of $400 \mathrm{~kg} \mathrm{ha}^{-1} \mathrm{Ca}$ before soil preparation. Seeds were machine-planted in rows $0.5 \mathrm{~m}$ apart, at $0.105 \mathrm{~m}$ in the row, immediately after disc-harrowing, ploughing and harrowing. Open spaces were replanted at emergence, resulting in densities of 160000 (Experiment 1, 20 DAP) and 175000 (Experiment 2, $14 \mathrm{DAP}$ ) plants ha ${ }^{-1}$. At planting, Rhizobium inoculum was given and $18 \mathrm{~kg} \mathrm{~N}, 37 \mathrm{~kg} \mathrm{P}$ and $74 \mathrm{~kg} \mathrm{~K}$ per hectare were 


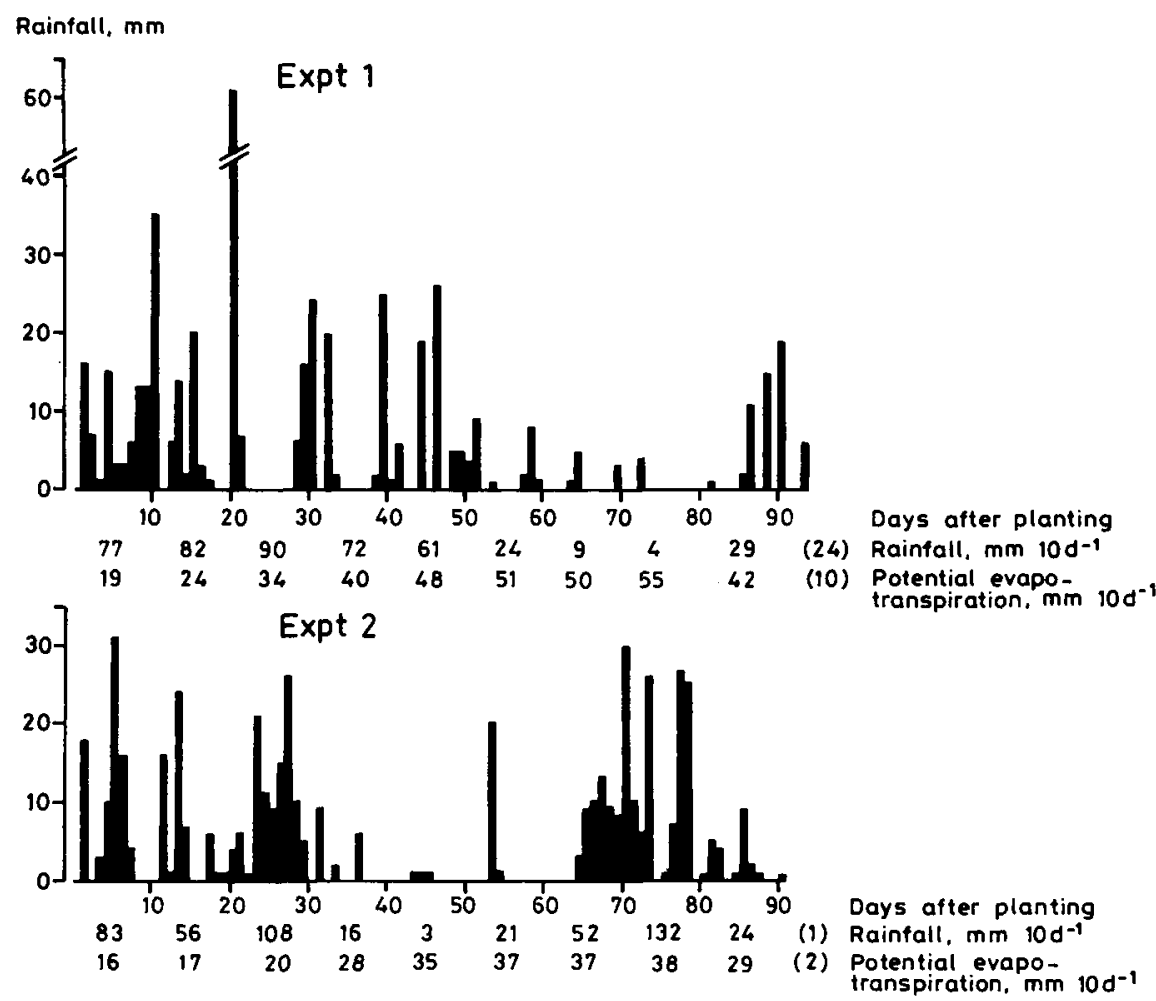

Figure. 1. Daily rainfall, and rainfall and potential evapotranspiration per ten days during the experiments.

Table 1. Chemical properties of the soil $(0-20 \mathrm{~cm})$ of the experimental fields.

\section{Experiment $1 \quad$ Experiment 2}

\begin{tabular}{|c|c|c|}
\hline Org. $\mathrm{C}, \mathrm{g} \mathrm{kg}^{-1}$ & 8.3 & 16.2 \\
\hline Org. $\mathrm{N}, \mathrm{g} \mathrm{kg}^{-1}$ & 0.6 & 1.3 \\
\hline $\mathrm{pH}-\mathrm{KCl}$ & 4.5 & 4.2 \\
\hline $\mathrm{pH}-\mathrm{H}_{2} \mathrm{O}$ & - & 5.3 \\
\hline Exch. $\mathrm{Ca}, \mathrm{mmol}(+) \mathrm{kg}^{-1}$ & 10.0 & 12.8 \\
\hline $\mathrm{Mg}, \operatorname{mmol}(+) \mathrm{kg}^{-1}$ & 0.4 & 4.9 \\
\hline $\mathrm{K}, \mathrm{mmol}(+) \mathrm{kg}^{-1}$ & 0.3 & 2.0 \\
\hline $\mathrm{Na}, \operatorname{mmol}(+) \mathrm{kg}^{-1}$ & 0.2 & 1.4 \\
\hline $\mathrm{Al}, \operatorname{mmol}(+) \mathrm{kg}^{-1}$ & 1.9 & 4.7 \\
\hline $\operatorname{ECEC}^{1}, \mathrm{mmol}^{(}+\mathrm{kg}^{-1}$ & 12.7 & 25.9 \\
\hline $100 \times$ exch. $\mathrm{Al} / \mathrm{ECEC}$ & 15 & 18 \\
\hline $\mathrm{CEC}^{2}, \mathrm{pH} 7, \mathrm{mmol}(+) \mathrm{kg}^{-1}$ & 23.8 & 43.9 \\
\hline P-Bray $\mathrm{I}, \mathrm{mg} \mathrm{kg}^{-1} \mathrm{P}$ & 30.7 & 29.6 \\
\hline
\end{tabular}

${ }^{1} \mathrm{ECEC}=$ Effective Cation Exchange Capacity; ${ }^{2} \mathrm{CEC}=$ Cation Exchange Capacity. 


\section{A.P. EVERAARTS}

band-placed near the seeds. Around four weeks after planting, gypsum, at the rate of $29 \mathrm{~kg} \mathrm{ha}^{-1} \mathrm{Ca}$, was applied over the rows. The early maturing Spanish type cultivar Matjan was used in both experiments. A fungicide for leafspot and rust control was routinely applied. Seeds were desinfected with a fungicide in the second experiment, but not in the first. Harvesting was done manually at 94 (Experiment 1) and 91 (Experiment 2) DAP.

\section{Experimental procedures}

The experiments had a randomized complete block design, replicated five times.

There were two series of six treatments. One series consisted of: (a) keeping the crop weed-free, by hand-weeding, for six periods of an increasing number of days from planting onwards, after which time weed growth was permitted. The other series consisted of: (b) allowing the weed vegetation to develop freely for identical periods as under (a), after which time the crop was weeded, and kept weed-free by hand. The plots consisted of four $7.5 \mathrm{~m}$ long rows and were subdivided into two $3 \mathrm{~m}$ long subplots comprising both centre rows. One subplot was set aside for the determination of final pod yield and yield components.

In the other subplot at the end of each weed-free period or period without weed control, the following observations were made:

- The degree of ground-cover of crop and weed vegetation was visually estimated.

- Of five crop plants the above-ground parts and pods were pooled and analysed for $\mathrm{N}, \mathrm{P}$ and $\mathrm{K}$ concentrations.

- Five other crop plants were used to determine main stem length (up to the node with the last fully unfolded leaf), the number of nodes on the main stem (the cotyledonary node as first node) and the number of branches, leaves and pods present. Total leaf area of these five plants was estimated using the punch disc method, punching, as a rule, twelve leaflets per plant. Dry weight of leaflets, leaf-discs, stems (including leaf-stalks and gynophores) and pods of these plants was determined after oven-drying at $85^{\circ} \mathrm{C}(24 \mathrm{~h})$ and $105^{\circ} \mathrm{C}(2 \mathrm{~h})$.

- The remaining plants in the subplot were counted and the dry weight of their above-ground parts and pods, was determined as above.

- In treatments (b), two $0.5 \times 0.6 \mathrm{~m}$ samples of the above-ground part of the weed vegetation were taken lengthwise over the crop row to determine $\mathrm{N}, \mathrm{P}$ and $\mathrm{K}$ concentrations and dry weight.

With this experimental design - apart from evaluating effects on final pod yield - based on the observations made at the end of each weed-free period or period without weed control, the pattern of growth and development of a completely weed-free crop and of a crop without weed control at all, and of the weeds, could be analysed and compared.

In Experiment 2, the spatial distribution of weed growth was determined in the pod yield subplots with weed growth at harvest. A sample area of $1 \times 1 \mathrm{~m}$ was used which was subdivided in five adjacent strips of $0.125,0.25,0.25,0.25$ and $0.125 \mathrm{~m}$ wide. 


\section{Weed species}

The weed vegetation in Experiment 1 consisted mainly of Eleusine indica (L.) Gaertn., with Physalis angulata L. and Euphorbia heterophylla L. of secondary importance. Eleusine indica dominated in Experiment 2, with Amaranthus dubius Mart. as a secondary species. Other species were of minor or no importance.

\section{Results and discussion}

\section{Ground-cover and leaf area index (LAI)}

In Experiment 1, ground-cover of the crop, irrespective of treatment, was highest around 50 DAP (Figure 2). It subsequently declined because of wilting and leaf-fall due to moisture shortage (Figure 1). When, at around 90 DAP, there was again adequate moisture, the crop with weed control recovered but the crop without did not. Weed growth in this experiment was not abundant. Ground-cover of the weed vegetation remained low and decreased towards harvest as a result of moisture shortage.

In Experiment 2, highest values for crop ground-cover, irrespective of treatment, were also reached in about 50 DAP. Competition effects on ground-cover became apparent between 27 and 49 DAP. From 49 DAP onwards, the difference

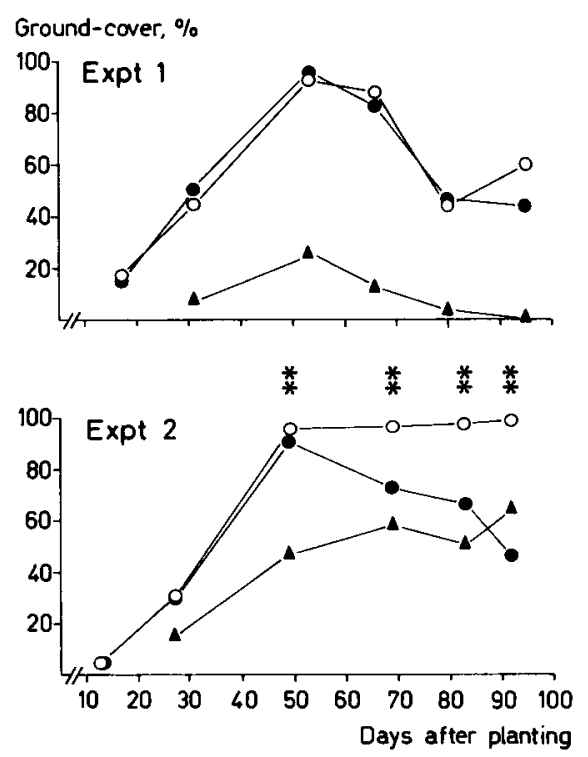

Figure 2. Ground-cover of the crop with $(O)$ and without $(O)$ weed control and of the weed vegetation $(\boldsymbol{\Lambda})$. Following a one-sided $t$-test a significant difference between treatments is indicated by ${ }^{* *}(P \leq$ $0.01)$. 


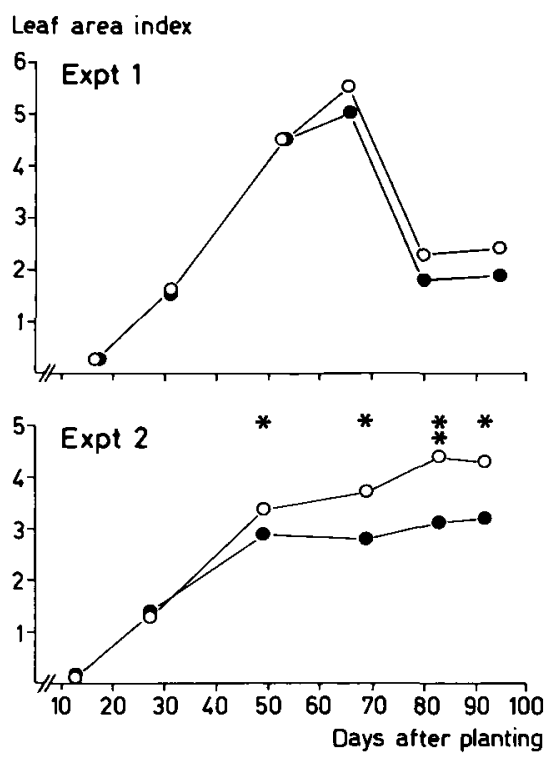

Figure 3. Leaf area index of the crop with $(O)$ and without $(\bullet)$ weed control. Following a one-sided $t$-test a significant difference between treatments is indicated by $*(P \leq 0.05)$ or ${ }^{* *}(P \leq 0.01)$.

in crop ground-cover - and hence in light interception - between the crop with and without weed control increased. Weed growth in Experiment 2, in terms of ground-cover, was much more abundant than in Experiment 1. The weeds overgrew the crop and intermingling of crop and weed canopy resulted in supersedence and less efficient positioning of the crop leaves, which contributed to the decline in crop ground-cover.

In Experiment 1, the LAI of the crop, irrespective of treatment, increased continuously until the onset of the period of drought, when LAI values abruptly declined due to withering and leaf-fall (Figure 3). Treatment effects became apparent between 53 and $66 \mathrm{DAP}$ and persisted until harvest. In Experiment 2 differences in LAI between the crop with and without weed control became evident between 27 and 49 DAP and increased with time.

\section{Dry weight}

In Experiment 1, dry weight of the crop without weed control was not affected by weed competition until the moisture supply became limiting and dry weight in both treatments decreased (Figure 4). Dry weight in both treatments was affected by leaf-fall. When the moisture supply became limiting, the weight of the weed vegetation decreased.

In Experiment 2, the lower ground-cover and LAI of the non-weeded crop will have reduced the assimilate supply. Effects of competition on dry weight appeared 

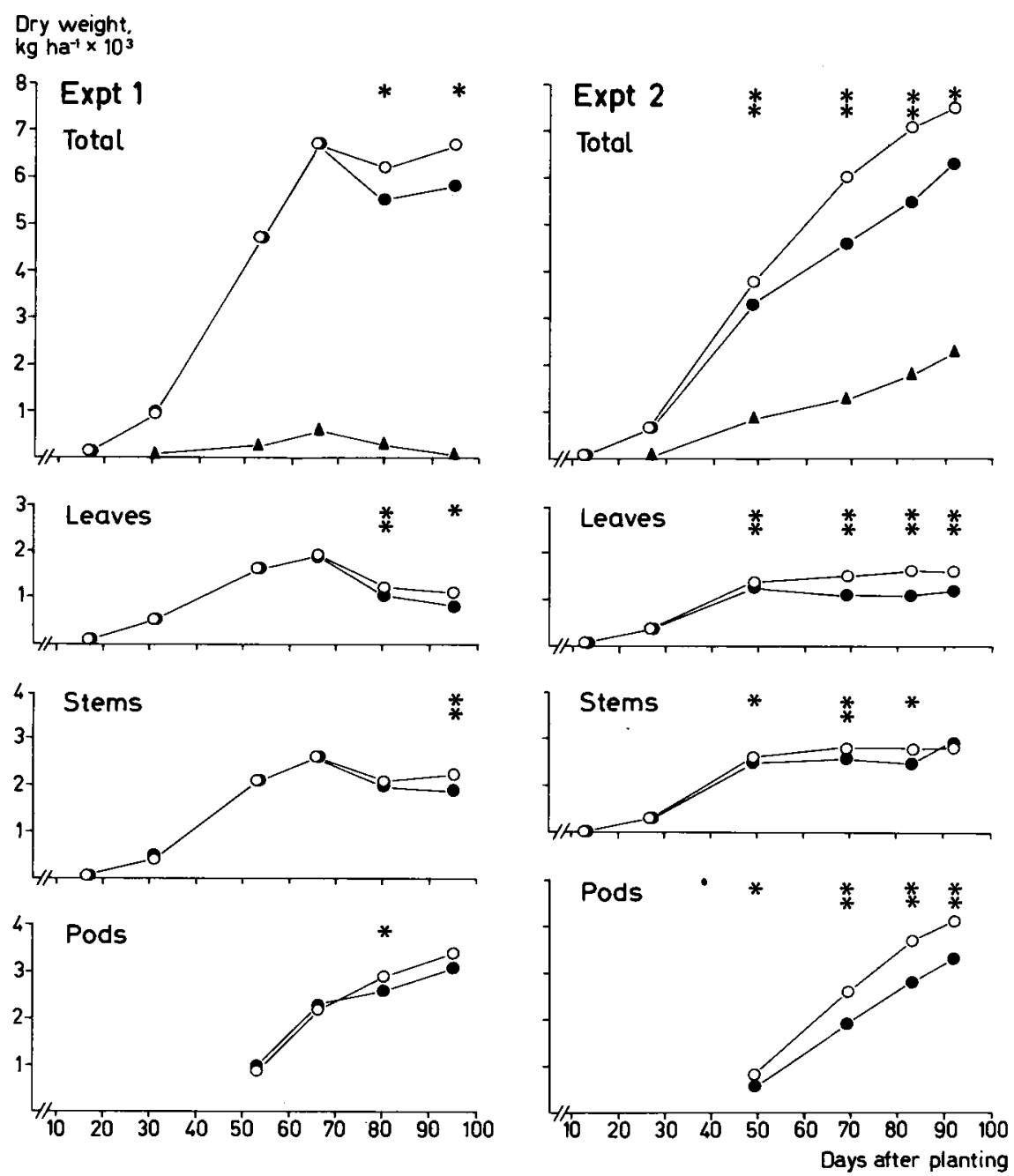

Figure 4. Dry weight (above-ground parts) of the crop with $(O)$ and without $(\bullet)$ weed control and of the weed vegetation $(\boldsymbol{\Lambda}$, above-ground parts). Following a one-sided $t$-test a significant difference between treatments is indicated by $*(P \leq 0.05)$ or $* *(P \leq 0.01)$.

between 27 and 49 DAP and persisted until harvest. Weed competition also influenced dry matter partitioning over the various plant parts. From 49 DAP onwards, relative stem weight was higher in the non-weeded crop at the expense of relative leaf and pod weight. Weed dry weight in Experiment 2 increased until harvest of the crop. 


\section{A.P. EVERAARTS}

Table 2. Development of the crop with and without weed control.

\begin{tabular}{|c|c|c|c|c|c|c|c|}
\hline \multirow[t]{2}{*}{ Experiment 1} & & \multicolumn{6}{|c|}{ Days after planting } \\
\hline & & 17 & 31 & 53 & 66 & 80 & 95 \\
\hline \multirow{2}{*}{$\begin{array}{l}\text { Number of plants } \\
\text { per } 3 \mathrm{~m}^{2}\end{array}$} & weed-free & 48 & 50 & 48 & 49 & 44 & 48 \\
\hline & no weed control & 49 & $46^{*}$ & 48 & 47 & 46 & 48 \\
\hline \multirow{2}{*}{$\begin{array}{l}\text { Length of main } \\
\text { stem }(\mathrm{cm})\end{array}$} & weed-free & 6.8 & 18.1 & 47.9 & 56.0 & 54.4 & 55.3 \\
\hline & no weed control & 5.6 & 18.4 & $50.6^{* *}$ & $59.1^{*}$ & 55.8 & 54.0 \\
\hline \multirow{2}{*}{$\begin{array}{l}\text { Number of nodes } \\
\text { on main stem }\end{array}$} & weed-free & 6 & 11 & 17 & 19 & $18^{+}$ & 19 \\
\hline & no weed control & 7 & 11 & 17 & 20 & 16 & 18 \\
\hline \multirow{2}{*}{$\begin{array}{l}\text { Length of inter- } \\
\text { nodes on main } \\
\text { stem }(\mathrm{cm})\end{array}$} & weed-free & 1.3 & 1.8 & 3.0 & 3.2 & $3.1^{+}$ & 3.1 \\
\hline & no weed control & 1.0 & 1.9 & 3.2 & 3.1 & 3.7 & 3.2 \\
\hline \multicolumn{2}{|l|}{ Experiment 2} & 13 & 27 & 49 & 69 & 83 & 92 \\
\hline \multirow{2}{*}{$\begin{array}{l}\text { Number of plants } \\
\text { per } 3 \mathrm{~m}^{2}\end{array}$} & weed-free & 51 & 52 & 52 & 53 & 51 & 51 \\
\hline & no weed control & 52 & 55 & 51 & 53 & 53 & 52 \\
\hline \multirow{2}{*}{$\begin{array}{l}\text { Length of main } \\
\text { stem }(\mathrm{cm})\end{array}$} & weed-free & 4.9 & 15.6 & 37.7 & 41.8 & 48.4 & 49.2 \\
\hline & no weed control & 4.9 & 15.7 & 39.0 & $45.6^{* *}$ & 49.1 & 53.4 \\
\hline \multirow{2}{*}{$\begin{array}{l}\text { Number of nodes } \\
\text { on main stem }\end{array}$} & weed-free & 5 & 9 & 12 & 13 & 16 & 17 \\
\hline & no weed control & 6 & 10 & 12 & 13 & $15^{*}$ & 16 \\
\hline \multirow{2}{*}{$\begin{array}{l}\text { Length of inter- } \\
\text { nodes on main } \\
\text { stem }(\mathrm{cm})\end{array}$} & weed-free & 1.1 & 2.0 & 3.4 & 3.4 & 3.2 & 3.1 \\
\hline & no weed control & 1.1 & 1.8 & $3.7^{*}$ & $3.9^{*}$ & $3.6^{* *}$ & $3.6^{* *}$ \\
\hline
\end{tabular}

Following a one-sided $t$-test a significant difference between treatments is indicated by $*(P \leq 0.05)$ or $* *(P \leq 0.01)$.

+ Based on two replicates.

\section{Development}

Plant density was not influenced by treatment in either experiment, except at 31 DAP in Experiment 1 (Table 2).

In both experiments, there was a tendency towards more elongated stems in response to presence of weeds (Table 2). In Experiment 1, this reaction started between 31 and 53 DAP. With the limited moisture supply, stem-lengths seem to have decreased and differences between treatments diminished. No consistent effects were observed on the number of nodes or on the length of the internodes in this experiment.

In Experiment 2, extra elongation of the main stem as a reaction to competition started between 27 and 49 DAP. The number of nodes tended to be lower without weed control and the length of the internodes increased. Extra elongation of the 
Table 3. Development of the crop with and without weed control.

\begin{tabular}{|c|c|c|c|c|c|c|c|}
\hline \multirow[t]{2}{*}{ Experiment 1} & & \multicolumn{6}{|c|}{ Days after planting } \\
\hline & & 17 & 31 & 53 & 66 & 80 & 95 \\
\hline \multirow{2}{*}{$\begin{array}{l}\text { Number of bran- } \\
\text { ches per plant }\end{array}$} & weed-free & 3 & 5 & 5 & 5 & 5 & 5 \\
\hline & no weed control & 4 & 5 & 5 & 5 & 5 & 5 \\
\hline \multirow{2}{*}{$\begin{array}{l}\text { Number of leaves } \\
\text { per plant }\end{array}$} & weed-free & 11 & 37 & 67 & 66 & 30 & 29 \\
\hline & no weed control & 12 & 36 & 66 & 70 & $12^{* *}$ & 25 \\
\hline \multirow{2}{*}{$\begin{array}{l}\text { Number of pods } \\
\text { per plant }\end{array}$} & weed-free & - & - & 29 & 31 & 30 & 31 \\
\hline & no weed control & - & - & 31 & 32 & 25 & 31 \\
\hline \multirow{2}{*}{$\begin{array}{l}\text { Dry weight per } \\
\text { pod }(\mathrm{g})\end{array}$} & weed-free & - & - & 0.20 & 0.44 & 0.68 & 0.67 \\
\hline & no weed control & - & - & 0.21 & 0.48 & 0.68 & 0.66 \\
\hline \multicolumn{2}{|l|}{ Experiment 2} & 13 & 27 & 49 & 69 & 83 & 92 \\
\hline \multirow{2}{*}{$\begin{array}{l}\text { Number of bran- } \\
\text { ches per plant }\end{array}$} & weed-free & 2 & 4 & 7 & 7 & 8 & 7 \\
\hline & no weed control & 2 & 4 & 7 & 7 & 7 & 7 \\
\hline \multirow{2}{*}{$\begin{array}{l}\text { Number of leaves } \\
\text { per plant }\end{array}$} & weed-free & 6 & 25 & 56 & 57 & 68 & 66 \\
\hline & no weed control & 5 & 26 & $49 *$ & $41^{*}$ & $50^{* *}$ & $53^{*}$ \\
\hline \multirow{2}{*}{$\begin{array}{l}\text { Number of pods } \\
\text { per plant }\end{array}$} & weed-free & - & - & 28 & 31 & 36 & 33 \\
\hline & no weed control & - & - & $21 *$ & 26 & $28^{*}$ & 27 \\
\hline \multirow{2}{*}{$\begin{array}{l}\text { Dry weight per } \\
\text { pod }(\mathrm{g})\end{array}$} & weed-free & - & - & 0.18 & 0.48 & 0.67 & 0.76 \\
\hline & no weed control & - & - & 0.15 & $0.41 * *$ & $0.59 *$ & 0.71 \\
\hline
\end{tabular}

Following a one-sided $t$-test a significant difference between treatments is indicated by $*(P \leq 0.05)$ or $* *(P \leq 0.01)$.

main stem and increased length of internodes as a result of competition was also noted by Hamada (1988). The extra elongation of the main stem, and probably of the branches as well, is likely to have increased the relative stem weight in the crop without weed control.

The number of branches per plant was not affected by treatment (Table 3). Reduced branching because of competition with weeds has been reported by Ishag (1971) and Hamada (1988). However, their observations refer to a 'spreading bunch' cultivar, and the reaction to competition with weeds may vary for different cultivars (Brown, 1965).

The number of leaves present per plant in Experiment 2, was significantly affected by treatment starting between 27 and 49 DAP (Table 3). From 49 to 69 DAP, the number of leaves in the non-weeded crop decreased, contributing to the decline in ground-cover and LAI in this treatment during that period (Figures 2, 
3). In Experiment 1, the number of leaves present was affected by leaf-fall due to drought, regardless of treatment (at 80 and 95 DAP only green, presumably still functioning leaves were counted). The effect, however, was more pronounced in the non-weeded crop.

Towards flowering, observations were made on the number of flowering plants and the number of inflorescences per plant. The presence of weeds had no effect on the timing of flowering or, at least initially, on the number of inflorescences per plant. The onset of flowering, defined as the moment that $50 \%$ of the plants had produced at least one flower, fell between 24 and 31 DAP in Experiment 1. At 31 DAP, $86 \%$ of all plants were in flower. In Experiment 2, the onset of flowering was between 23 and 26 DAP. In both treatments, $92 \%$ of the plants were flowering by 27 DAP. Neither the percentage of flowering plants nor the number of inflorescences per plant, at 31 DAP in Experiment 1 or at 27 DAP in Experiment 2 , were influenced by the treatment.

In Experiment 2, the number of pods per plant and weight per pod were lower in the absence of weed control (Table 3 ). The absence of a decrease in the number of pods in the non-weeded crop with continued competition, indicates that abortion of pods did not occur. In Experiment 1, significant differences in the number of pods per plant or in weight per pod between treatments, were absent, although total dry weight of the pods was affected (Figure 4). This discrepancy between difference in total pod dry weight, and absence of difference between weight per pod, and the low number of pods in the non-weeded crop at 80 DAP in this experiment, are perhaps partly the result of harvesting difficulties due to the fragile state of the crop under the prevailing dry conditions.

There could be several reasons for the lower number of pods per plant in the non-weeded crop. In Experiment 2 for example, the number of flowers could have been reduced. However, as generally many more flowers are produced than pods (Williams et al., 1975), a smaller number of flowers can, at least partly, be compensated for by a higher percentage of flowers producing pods. This reaction was observed by Ishag (1971), who found that the absence of weed control certainly suppressed the production of flowers but, at the same time, increased the percentage of fruit set.

Hamdoun (1977) noted, that with extended internodes it takes longer before the gynophores reach the soil surface. Such a time lag, resulting in a lower number of pods present, would also result in a lower weight per pod which, in fact, was found (Table 3). It would, however, also have resulted in a lower percentage of mature kernels and a lower shelling percentage at maturity, which was not the case. It is possible, that the longer internodes require a length of gynophores exceeding a critical maximum value, thereby reducing the number of pods, but it seems doubtful whether the stem extension observed would have such a marked effect.

The most plausible explanation for the lower number of pods per plant is that the number of flowers producing gynophores, or the number of gynophores producing pods, was affected due to reduced assimilate supply. 
Table 4. Nutrient uptake ( $\mathrm{kg} \mathrm{ha}^{-1}$ ) of the crop (above-ground parts and pods), with and without weed control, and of the weeds (above-ground parts).

\begin{tabular}{|c|c|c|c|c|c|c|c|}
\hline \multicolumn{2}{|c|}{ Experiment 1} & \multicolumn{6}{|c|}{ Days after planting } \\
\hline & & 17 & 31 & 53 & 66 & 80 & 95 \\
\hline N Crop & weed-free & 7 & 37 & 131 & 180 & 157 & 187 \\
\hline Crop & no weed control & 7 & 37 & 130 & 177 & 147 & $160^{*}$ \\
\hline Weeds & & - & 4 & $5^{+}$ & 14 & 4 & 1 \\
\hline P Crop & weed-free & 0.8 & 3.0 & 10.3 & 13.3 & 12.3 & 14.0 \\
\hline Crop & no weed control & 0.7 & 3.0 & 10.0 & 12.7 & 11.7 & 12.7 \\
\hline Weeds & & - & 0.6 & $1.2^{+}$ & 3.8 & 1.4 & 0.2 \\
\hline K Crop & weed-free & 5 & 33 & 83 & 107 & 110 & 100 \\
\hline Crop & no weed control & 5 & 32 & 91 & 107 & $93^{*}$ & $70^{* *}$ \\
\hline Weeds & & - & 4 & $9^{+}$ & 23 & 10 & 1 \\
\hline Experiment & & 13 & 27 & 49 & 69 & 83 & 92 \\
\hline N Crop & weed-free & 5 & 28 & 106 & 173 & 213 & 260 \\
\hline Crop & no weed control & 5 & 29 & $91^{*}$ & $140^{* *}$ & $177^{*}$ & $197 * *$ \\
\hline Weeds & & - & 5 & 21 & 29 & 38 & 38 \\
\hline P Crop & weed-free & 0.4 & 2.4 & 10.3 & 13.7 & 16.7 & 20.0 \\
\hline Crop & no weed control & 0.5 & 2.5 & 9.7 & $10.7^{* *}$ & $13.7^{* *}$ & $14.7^{* * *}$ \\
\hline Weeds & & - & 0.7 & 3.0 & 3.3 & 4.0 & 5.7 \\
\hline K Crop & weed-free & 3 & 25 & 98 & 120 & 137 & 127 \\
\hline Crop & no weed control & 3 & 25 & 84 * & 100 & $93^{*}$ & 117 \\
\hline Weeds & & - & 7 & 37 & 44 & 62 & 74 \\
\hline
\end{tabular}

Following a one-sided $t$-test a significant difference between treatments is indicated by ${ }^{*}(P \leq 0.05)$ or $* *(P \leq 0.01)$.

+ Based on four replicates.

\section{Nature of competitive effects}

\section{Nutrients}

The amount of nutrients taken up by the weeds in Experiment 1 is small compared with the amount taken up by the crop (Table 4). Nutrient uptake of the crop in this experiment was not strongly influenced by treatment. The amount of $K$ in the crop, irrespective of treatment, and in the weeds, decreases towards harvest. Therefore the significantly lower amount of $\mathrm{K}$ and the lower $\mathrm{K}$ concentration at the end of the crop growth period (Table 5) are unlikely to be the result of competitive effects on uptake. The lower $\mathrm{P}$ and $\mathrm{K}$ concentrations in the absence of weeding at 31 DAP (Table 5) were only temporary and may have been the result of a short period of limited moisture availability just before 31 DAP (Figure 1). Where weeds were present, moisture stress in the uppermost soil layers may 


\section{A.P. EVERAARTS}

Table 5. Nutrient concentration ( $\mathrm{g} \mathrm{kg}^{-1}$ ) of the crop (above-ground parts and pods), with and without weed control, and of the weeds (above-ground parts).

\begin{tabular}{|c|c|c|c|c|c|c|c|}
\hline \multirow[t]{2}{*}{ Experiment } & & \multicolumn{6}{|c|}{ Days after planting } \\
\hline & & 17 & 31 & 53 & 66 & 80 & 95 \\
\hline N Crop & weed-free & 38.1 & 38.4 & 28.0 & 27.0 & 25.0 & 28.0 \\
\hline Crop & no weed control & 38.4 & 36.4 & 27.7 & 26.7 & 26.6 & 27.9 \\
\hline Weeds & & - & 36.0 & $24.5^{+}$ & 22.1 & 15.6 & 13.5 \\
\hline P Crop & weed-free & 4.4 & 3.2 & 2.2 & 2.0 & 2.0 & 2.1 \\
\hline Crop & no weed control & 4.3 & $3.0^{*}$ & 2.2 & 1.9 & 2.1 & 2.2 \\
\hline Weeds & & - & 5.9 & $5.9^{+}$ & 5.4 & 5.3 & 2.8 \\
\hline K Crop & weed-free & 30.4 & 34.2 & 17.7 & 16.0 & 17.8 & 14.9 \\
\hline Crop & no weed control & 30.2 & $32.0^{*}$ & 19.4 & 16.2 & 17.0 & $12.1 *$ \\
\hline Weeds & & - & 43.1 & $44.4^{+}$ & 35.3 & 34.8 & 17.5 \\
\hline Experimen & & 13 & 27 & 49 & 69 & 83 & 92 \\
\hline N Crop & weed-free & 54.8 & 43.8 & 27.8 & 29.2 & 30.2 & 34.3 \\
\hline Crop & no weed control & 55.0 & 43.2 & 27.4 & 30.5 & 32.1 & $31.2^{*}$ \\
\hline Weeds & & - & 36.9 & 23.6 & 22.3 & 20.5 & 16.7 \\
\hline P Crop & weed-free & 4.8 & 3.7 & 2.7 & 2.3 & 2.3 & 2.6 \\
\hline Crop & no weed control & 5.0 & 3.8 & 2.9 & 2.3 & 2.5 & $2.3 * *$ \\
\hline Weeds & & - & 3.7 & 3.6 & 2.5 & 2.2 & 2.4 \\
\hline K Crop & weed-free & 35.8 & 39.2 & 25.8 & 20.4 & 19.1 & 16.9 \\
\hline Crop & no weed control & 35.7 & 37.0 & 25.2 & 21.6 & 16.8 & 18.3 \\
\hline Weeds & & - & 51.1 & 40.6 & 33.1 & 36.1 & 32.4 \\
\hline
\end{tabular}

Following a one-sided $t$-test a significant difference between treatments is indicated by $*(P \leq 0.05)$ or $* *(P \leq 0.01)$.

${ }^{+}$Based on four replicates.

have become critical, thereby reducing nutrient uptake. Bunting \& Anderson (1960) found strong negative effects of drought on the uptake of P.

In Experiment 2, the uptake of $\mathrm{N}, \mathrm{P}$ and $\mathrm{K}$ by the crop without weed control was considerably lower than that of the weed-free crop. However, with the exception of $\mathrm{N}$ and $\mathrm{P}$ at harvest, differences in nutrient uptake were not accompanied by lower nutrient concentrations in the non-weeded crop, indicating that nutrient uptake was not determined by availability of the nutrient, but by the demand of the crop, which is a function of its dry weight.

These results show, that despite the low soil fertility (Table 1), competition for nutrients was absent in both experiments. Several factors may have contributed to this situation: (a) the groundnut crop fixes most of its own nitrogen, and with this capacity apparently not affected by the competition with weeds, competition for $\mathrm{N}$ was avoided; (b) groundnuts are able to root deeply and are likely to have 
rooted deeper than the weeds, and as weed growth was mainly concentrated between the rows (see 'Spatial distribution of weed growth'), the crop and weeds may have explored partly different soil volumes; (c) the band-placement of the fertilizer near the crop seeds ensured better access to the nutrients applied for the crop than for the weeds.

\section{Light}

In Experiment 2, weeds overgrew the crop, resulting in considerable shading of the crop, which is the reason for the extra elongation of the internodes (Table 2). At 62 DAP, average canopy height of the weed-free as well as of the non-weeded crop was between 0.4 and $0.5 \mathrm{~m}$. Light measurements at this date showed that the intensity of visible light at $0.4 \mathrm{~m}$ above ground-level in the non-weeded crop was $72 \%$ of that in the weed-free crop. At 0.3 and $0.2 \mathrm{~m}$ above ground-level, these percentages were 51 and 41 , respectively. These data indicate competition for light. Shading of the crop by the weeds was not strong in Experiment 1. No light measurements were taken. Indications for shading are the extra elongated stems in the non-weeded crop at 53 and 66 DAP.

\section{Water}

In Experiment 2, potential evapotranspiration of a weed-free crop exceeded the moisture supply between around 35 to about 65 DAP (Figure 1). As the available moisture storage capacity of the Zanderij soils is low (Boxman et al., 1985), a contribution to available moisture from this source is not taken into account. In view of the combined ground-cover of the non-weeded crop and weeds it is likely that competition for water between the non-weeded crop and weeds occurred in this period. Evidence of water deficiency in the non-weeded crop in the period 49 to $69 \mathrm{DAP}$ is found in the decrease in the number of leaves (Table 3 ), with the associated decrease in LAI (Figure 3).

In Experiment 1, severe moisture stress, starting between 50 and 60 DAP, affected growth of the crop irrespective of the presence of weeds and induced differences between the treatments (Figure 4, Table 3).

\section{Yield}

\section{Weed-free period after planting}

Keeping the crop weed-free for longer than 17 DAP in Experiment 1 did not lead to a significant increase in yield (Table 6). In Experiment 2, 13 weed-free DAP were sufficient to avoid yield losses, and in both experiments even shorter periods might have sufficed. In neither experiment did the length of the weed-free period significantly or consistently affect plant density, 1000-seed weight, shelling percentage or percentage of sound mature kernels.

It would appear therefore that, compared with the weeding in general required 


\section{A.P. EVERAARTS}

Table 6. Yield (12\% moisture) and yield components with increasing periods with and without weed control.

\begin{tabular}{|c|c|c|c|c|c|c|c|}
\hline \multirow[t]{2}{*}{ Experiment 1} & & \multicolumn{6}{|c|}{ Period, days after planting } \\
\hline & & $0-17$ & $0-31$ & $0-53$ & $0-66$ & $0-80$ & $0-94$ \\
\hline $\begin{array}{l}\text { Pod yield } \\
\qquad\left(\mathrm{kg} \mathrm{ha}^{-1}\right)\end{array}$ & $\begin{array}{l}\text { weed-free } \\
\text { no weed control }\end{array}$ & $\begin{array}{l}3672 \mathrm{a} \\
3860 \mathrm{a}\end{array}$ & $\begin{array}{l}3578 \text { a } \\
3723 \text { a }\end{array}$ & $\begin{array}{l}3565 \mathrm{a} \\
3450 \mathrm{ab}\end{array}$ & $\begin{array}{l}3748 \text { a } \\
3392 \text { ab }\end{array}$ & $\begin{array}{l}3512 \mathrm{ab} \\
3063 \mathrm{~b}\end{array}$ & $\begin{array}{l}3879 \mathrm{a} \\
3452 \mathrm{ab}\end{array}$ \\
\hline $\begin{array}{l}\text { Number of } \\
\text { plants per } 3 \mathrm{~m}^{2}\end{array}$ & $\begin{array}{l}\text { weed-free } \\
\text { no weed control }\end{array}$ & $\begin{array}{l}46 \\
46\end{array}$ & $\begin{array}{l}47 \\
45\end{array}$ & $\begin{array}{l}43 \\
45\end{array}$ & $\begin{array}{l}46 \\
46\end{array}$ & $\begin{array}{l}46 \\
46\end{array}$ & $\begin{array}{l}47 \\
47\end{array}$ \\
\hline $\begin{array}{l}\text { 1000-seed } \\
\text { weight }(\mathrm{g})\end{array}$ & $\begin{array}{l}\text { weed-free } \\
\text { no weed control }\end{array}$ & $\begin{array}{l}618 \\
626\end{array}$ & $\begin{array}{l}597 \\
596\end{array}$ & $\begin{array}{l}629 \\
621\end{array}$ & $\begin{array}{l}603 \\
622\end{array}$ & $\begin{array}{l}583 \\
624\end{array}$ & $\begin{array}{l}608 \\
609\end{array}$ \\
\hline $\begin{array}{l}\text { Shelling } \\
\text { percentage }\end{array}$ & $\begin{array}{l}\text { weed-free } \\
\text { no weed control }\end{array}$ & $\begin{array}{l}73.7 \\
74.0\end{array}$ & $\begin{array}{l}73.9 \\
73.6\end{array}$ & $\begin{array}{l}73.8 \\
74.6\end{array}$ & $\begin{array}{l}73.8 \\
75.2\end{array}$ & $\begin{array}{l}73.5 \\
74.4\end{array}$ & $\begin{array}{l}73.9 \\
74.7\end{array}$ \\
\hline $\begin{array}{r}\text { Sound mature } \\
\text { kernels (\%) }\end{array}$ & $\begin{array}{l}\text { weed-free } \\
\text { no weed control }\end{array}$ & $\begin{array}{l}87.6 \\
88.3\end{array}$ & $\begin{array}{l}86.6 \\
88.2\end{array}$ & $\begin{array}{l}89.0 \\
88.7\end{array}$ & $\begin{array}{l}83.8 \\
89.5\end{array}$ & $\begin{array}{l}80.7 \\
85.7\end{array}$ & $\begin{array}{l}87.2 \\
87.9\end{array}$ \\
\hline Experiment 2 & & $0-13$ & $0-27$ & $0-49$ & $0-69$ & $0-83$ & $0-91$ \\
\hline $\begin{array}{l}\text { Pod yield } \\
\qquad\left(\mathrm{kg} \mathrm{ha}^{-1}\right)\end{array}$ & $\begin{array}{l}\text { weed-free } \\
\text { no weed control }\end{array}$ & $\begin{array}{l}4645 \mathrm{a} \\
4590 \mathrm{a}\end{array}$ & $\begin{array}{l}4654 a \\
4628 \mathrm{a}\end{array}$ & $\begin{array}{l}4576 \mathrm{a} \\
4238 \mathrm{a}\end{array}$ & $\begin{array}{l}4497 \mathrm{a} \\
3563 \mathrm{~b}\end{array}$ & $\begin{array}{l}4736 \mathrm{a} \\
3608 \mathrm{~b}\end{array}$ & $\begin{array}{l}4520 \mathrm{a} \\
3544 \mathrm{~b}\end{array}$ \\
\hline $\begin{array}{l}\text { Number of } \\
\text { plants per } 3 \mathrm{~m}^{2}\end{array}$ & $\begin{array}{l}\text { weed-free } \\
\text { no weed control }\end{array}$ & $\begin{array}{l}53 \\
53\end{array}$ & $\begin{array}{l}51 \\
53\end{array}$ & $\begin{array}{l}50 \\
53\end{array}$ & $\begin{array}{l}53 \\
51\end{array}$ & $\begin{array}{l}52 \\
53\end{array}$ & $\begin{array}{l}52 \\
49\end{array}$ \\
\hline $\begin{array}{l}\text { 1000-seed } \\
\text { weight }(\mathrm{g})\end{array}$ & $\begin{array}{l}\text { weed-free } \\
\text { no weed control }\end{array}$ & $\begin{array}{l}691 \\
711\end{array}$ & $\begin{array}{l}706 \\
699\end{array}$ & $\begin{array}{l}700 \\
691\end{array}$ & $\begin{array}{l}711 \\
705\end{array}$ & $\begin{array}{l}712 \\
703\end{array}$ & $\begin{array}{l}695 \\
697\end{array}$ \\
\hline $\begin{array}{l}\text { Shelling } \\
\text { percentage }\end{array}$ & $\begin{array}{l}\text { weed-free } \\
\text { no weed control }\end{array}$ & $\begin{array}{l}73.1 \mathrm{ab} \\
74.0 \mathrm{ab}\end{array}$ & $\begin{array}{l}73.5 \mathrm{ab} \\
74.0 \mathrm{ab}\end{array}$ & $\begin{array}{l}72.8 \mathrm{a} \\
73.8 \mathrm{ab}\end{array}$ & $\begin{array}{l}73.5 \mathrm{ab} \\
74.3 \mathrm{abc}\end{array}$ & $\begin{array}{l}73.1 \mathrm{ab} \\
74.4 \mathrm{bc}\end{array}$ & $\begin{array}{l}73.3 \mathrm{ab} \\
75.7 \mathrm{c}\end{array}$ \\
\hline $\begin{array}{r}\text { Sound mature } \\
\text { kernels (\%) }\end{array}$ & $\begin{array}{l}\text { weed-free } \\
\text { no weed control }\end{array}$ & $\begin{array}{l}83.9 \mathrm{~d} \\
89.6 \mathrm{abc}\end{array}$ & $\begin{array}{l}88.3 \mathrm{abd} \\
88.4 \mathrm{abd}\end{array}$ & $\begin{array}{l}86.4 \mathrm{ad} \\
90.6 \mathrm{abc}\end{array}$ & $\begin{array}{l}88.8 \mathrm{abc} \\
89.6 \mathrm{abc}\end{array}$ & $\begin{array}{l}88.3 \mathrm{abd} \\
93.3 \mathrm{c}\end{array}$ & $\begin{array}{l}87.2 \mathrm{ad} \\
92.3 \mathrm{bc}\end{array}$ \\
\hline
\end{tabular}

For each variable, figures followed by the same letter are not significantly different $(P \leq 0.05)$ according to Duncan's New Multiple Range Test (n.s. = non-significant).

after planting, in this case a rather short weed-free period sufficed to avoid losses.

Weed growth following the weed-free periods was assessed and found negligible. At harvest in Experiment 1, a measurable amount of weeds $\left(0.6 \mathrm{~kg} \mathrm{ha}^{-1}\right)$ was only found in the crop that had been kept weed-free for 31 DAP. At harvest in Experiment 2, weed growth was found only in the crop kept weed-free for 13 DAP ( $\left.24 \mathrm{~kg} \mathrm{ha}^{-1}\right)$. The crop thus had an obvious competitive advantage over the weeds after some time of weed-free conditions. 


\section{Period after planting without weed control}

Competitive effects in Experiment 1 were not clearly expressed in yield (Table 6), as they were mainly induced by the severe drought which affected crop growth in both treatments (Figure 4). Increasing the period without weed control, however, tended to decrease yield. A substantially reduced yield was found for the crop not weeded for 80 DAP. Because the yield of the crop with no weed control at all was not so much reduced, this yield reduction must at least partly be ascribed to the inevitable disturbance of the crop during removal of weeds at 80 DAP under the prevailing dry conditions.

Plant density, 1000-seed weight, shelling percentage, and percentage of sound mature kernels in this experiment were not influenced by the length of the period without weed control.

Prolonged periods without weed control resulted in yield reduction in Experiment 2. Yield reduction was $22 \%$ without any weed control. This is low compared with losses reported in the literature (Ashrif, 1967; Goldson, 1967; Bhan et al., 1971; Schiller et al., 1976; Singh et al., 1985), which may range from 40 to $80 \%$ or more. The method of cultivation, including band-placement of the fertilizers, gave the crop an advantage in competition, resulting in comparatively low yield reductions.

Delaying weed control up to 49 DAP caused a small yield reduction. Longer periods without weed control significantly reduced yields. As differences in plant density and 1000-seed weight were not significant, and shelling percentage and percentage of sound mature kernels were not negatively influenced, the main determinant of yield reduction was the lower number of pods per plant (see Table 3). Similar observations were made by Ishag (1971) and Hammerton (1976).

Whether a reduction in number of seeds per pod has contributed to the yield reduction is not known, but, in view of the relatively small reduction in weight per pod (Table 3), this seems unlikely. Moreover, this would probably have resulted in a decrease in shelling percentage, which was not found.

The number of pods per plant was mainly determined before 69 DAP (Table 3). Potential yield loss through reduction in the number of pods at 49 DAP could apparently still, although not entirely, be recovered from by removal of the weeds. Removal of weeds at 69 DAP or later resulted in loss of yield. Nevertheless, the assimilation capacity of the crop with no weed control at all was sufficient to increase shelling percentage and percentage of sound mature kernels (Table 6). This suggests that, in spite of the continued increase in weed weight after 69 DAP, the degree of weed competition decreased towards crop harvest, possibly as a result of maturing in the weed vegetation. The increase in shelling percentage and percentage of sound mature kernels partly compensated for the loss of yield through reduction in the number of pods.

These data indicate that the stage during which the number of pods per plant is determined, i.e. the period around 35 to $60 \mathrm{DAP}$, is critical to avoid competition with weeds. The weed-free period generally required in the tropics - four to eight weeks after planting - seems to corroborate this conclusion, as do the data of 


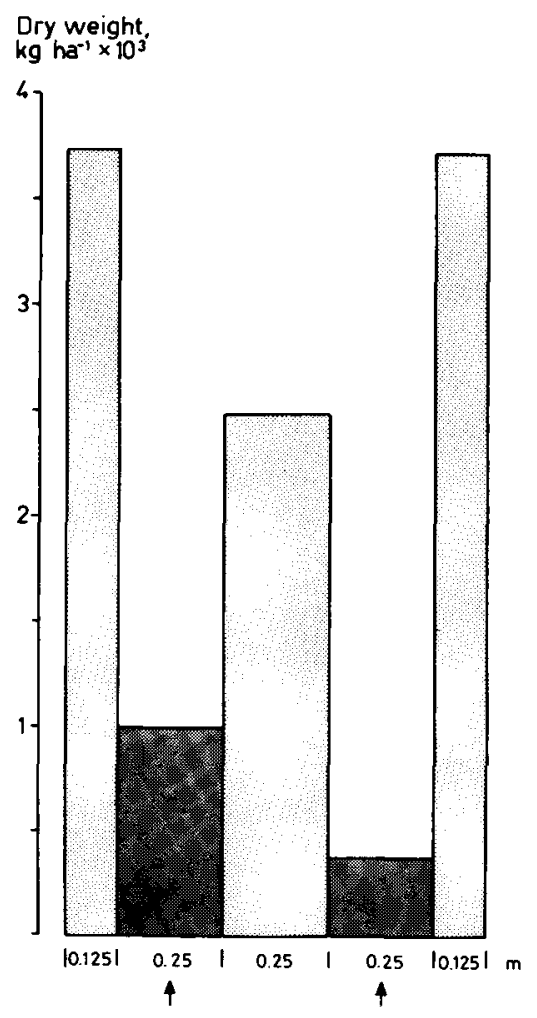

Figure 5. Spatial distribution of uncontrolled weed growth at harvest (Experiment 2; crop rows indicated by arrows).

Chamblee et al. (1982), who worked under temperate conditions. Van Heemst (1985) stated - based on literature - that the critical period for crop-weed competition in groundnuts started immediately at planting and ended at $35 \%$ of the length of the total crop growth period. In Experiment 2 a relatively long period of absence of weed control after planting could be tolerated without yield loss. The start of the critical period for crop-weed competition will be influenced by the conditions for crop and weed establishment at planting.

Increased periods without weed control did not influence plant density. An effect on plant density will depend on weed density and type of weed growth. In the literature (Ashrif, 1967; Bhan et al., 1971; Hamdoun, 1976, 1977; Hammerton, 1976; Hamada, 1988; Hamada et al., 1988), absence of effects and negative effects are both reported.

\section{Spatial distribution of weed growth}

At harvest, weed growth in Experiment 2 was concentrated between the rows (Figure 5). Band-placement of the fertilizer gave the crop good access to the nutrients and limited access by the weeds (Everaarts, 1991), thus giving the crop 
an advantage over the weeds. Due to large seed size, groundnuts have a large seedling and can rapidly establish some ground-cover. Due to rapid canopy closure in the row, weed growth was mainly limited to the space between the rows. With soybeans grown under the same conditions, an identical spatial distribution of weed growth was found (Everaarts, 1992). With sorghum, however, more weed growth was found in the rows than between them, mainly because of a more open canopy structure (Everaarts, 1991).

\section{Practical implications}

Because of the spatial distribution of weed growth, weed control should be concentrated on the weeds between the rows. In view of the only short weed-free period required after planting and to develop alternatives for chemical weed control, it is considered necessary to investigate whether one or two mechanical weeding rounds, between 10 to around $20 \mathrm{DAP}$ - before flowering to avoid damage to inflorescences - would be sufficient for the control of weeds. The weeding should then be done as widely as possible between the rows. Decreasing row width could further contribute to crop competitiveness (Buchanan \& Hauser, 1980; Hauser \& Buchanan, 1981). Weeds in the row are difficult to control mechanically, i.e. by burying, without damaging the crop. Whether or not these weeds can be neglected without consequence must also be examined, because apart from possible competitive effects, they may interfere with harvesting operations.

\section{Acknowledgements}

The author would like to thank personnel of CELOS, J. Duynhouwer and E. Vrancken for their assistance in carrying out the experiments. Dr D. Goense is kindly thanked for calculating the potential evapotranspiration.

\section{References}

Ashrif, M.I., 1967. Effects of fertilizer, weeding and pre-emergence MCPB on groundnuts in the Gambia, PANS (C) 13: 207-214.

Bhan, V.M., Megh Singh \& R.A. Maurya, 1971. Crop weed competition studies in groundnut. Indian Journal of Weed Science 3: 32-36.

Boxman, O., D. Goense, B.H. Janssen, J.J. Neeteson \& J.F. Wienk, 1985. The effect of moisture stress on the response to nitrogen by maize in the humid tropics of Suriname. In: B.T. Kang \& J. van der Heide (Eds), Nitrogen management in farming systems in humid and subhumid tropics, p. 199-214. IB, Haren; IITA, Ibadan.

Brown, P., 1965. A review of groundnut experiments in Malawi. Rhodesian Journal of Agricultural Research 3: 39-50.

Buchanan, G.A. \& E.W. Hauser, 1980. Influence of row spacing on competitiveness and yield of peanuts (Arachis hypogaea). Weed Science 28: 401-409.

Bunting, A.H. \& B. Anderson, 1960. Growth and nutrient uptake of Natal Common groundnuts in Tanganyika. Journal of Agricultural Science (Cambridge) 55: 35-46.

Carson, A.G., 1976. Weed competition and control in groundnuts (Arachis hypogaea L.). Ghana Journal of Agricultural Science 9: 169-173.

Chamblee, R.W., L. Thompson Jr. \& H.D. Coble, 1982. Interference of Broadleaf Signal grass 


\section{A.P. EVERAARTS}

(Brachiaria platyphylla) in peanuts (Arachis hypogaea). Weed Science 30: 45-49.

Doorenbos, J. \& W.O. Pruitt, 1977. Crop water requirements. FAO Irrigation and drainage paper 24. FAO, Rome, 144 pp.

Drennan, D.S.H. \& E.A. Jennings, 1977. Weed competition in irrigated cotton (Gossypium barbadense L.) and groundnut (Arachis hypogaea L.) in the Sudan Gezira. Weed Research 17: 3-9.

Dumas, R.E. \& S. Ausan, 1978. Research results and practical experiences regarding weed control in peanuts in Suriname. Proceedings Carribean Food Crops Society 15: 272-287.

Everaarts, A.P., 1991. Competition between crops and weeds in the Zanderij area of Suriname. Doctoral Thesis, Wageningen Agricultural University, Netherlands, $129 \mathrm{pp}$.

Everaarts, A.P., 1992. Effects of competition with weeds on growth, development and yield of soybeans. Netherlands Journal of Agricultural Science 40: 91-107.

Goldson, J.R., 1967. Weeding requirements of groundnuts in Western Kenya. East African Agricultural and Forestry Journal 32: 246-249.

Hamada; A.A., 1988. Weed competition in irrigated groundnuts, variety Ashford, in the Rahad Scheme, Sudan. Beiträge zur Tropischen Landwirtschaft und Veterinärmedizin 26: 25-31.

Hamada, A.A., E.A. Babiker \& F.M. Khalifa, 1988. Effect of weeds, nitrogen and phosphorus fertilizers on pod yield and growth of groundnuts at Rahad (Sudan). Oléagineux 43: 379-382.

Hamdoun, A.M., 1976. Chemical weed control in groundnuts in the Kenana area of the Sudan. Experimental Agriculture 12: 113-119.

Hamdoun, A.M., 1977. Competitive effects of weeds upon growth and yield of cotton, groundnuts and sorghum in the Kenana area of the Sudan. Journal of Plant Diseases and Protection 84: 509-515.

Hammerton, J.L., 1976. Problems of herbicide assessment in peanuts in Jamaica. Weed Research 16: 27-35.

Hauser, E.W. \& G.A. Buchanan, 1981. Influence of row spacing, seeding rates and herbicide systems on the competitiveness and yield of peanuts. Peanut Science 8: 74-81.

Heemst, H.D.J. van, 1985. The influence of weed competition on crop yield. Agricultural Systems 18: 81-93.

Ishag, H.M., 1971. Weed control in irrigated groundnuts (Arachis hypogaea L.) in the Sudan Gezira Journal of Agricultural Science (Cambridge) 77: 237-242.

Janssen, B.H. \& J.F. Wienk (Eds), 1990. Mechanized annual cropping on low fertility acid soils in the humid tropics. A case study of the Zanderij soils in Suriname. Wageningen Agricultural University Papers $90.5,230 \mathrm{pp}$.

Lagoke, S.T.O., A.H. Choudhary \& Y.M. Tanko, 1981. Weed control in rainfed groundnut (Arachis hypogaea L.) in the Guinea savanna zone of Nigeria. Weed Research 21: 119-125.

Rethinam, P., G. Selvaranga Raju, N. Sankaran, S. Sankaran \& Y.B. Morachan, 1976. Studies on crop-weed competition and chemical weed control in groundnut. Madras Agricultural Journal 63: 454-457.

Schiller, J.M., Prasart Dogkeaw \& Prasit Jina, 1976. Weed control in rainfed peanut (Arachis hypogaea L.) production in Northern Thailand. Thai Journal of Agricultural Science 9: 51-65.

Singh, A., R.S. Panwar, V.M. Bhan \& R.K. Malik, 1985. Effect of different periods of weed free maintenance on crop weed competition in groundnut (Arachis hypogaea L.). Indian Journal of Weed Science 17: 9-14.

Smartt, J., 1964. Factors influencing yield and quality of groundnuts in Northern Rhodesia. Empire Journal of Experimental Agriculture 32: 343-351.

Williams, J.H., J.H.H. Wilson \& G.C. Bate, 1975. The growth and development of four groundnut (Arachis hypogaea L.) cultivars in Rhodesia. Rhodesian Journal of Agricultural Research 13: 131144.

Yadav, S.K., S.P. Singh \& V.M. Bhan, 1984. Crop-weed competition studies in groundnut (Arachis hypogaea L.). Journal of Agricultural Science (Cambridge) 103: 373-376. 